\title{
Analysis of the diversity and evenness of mangrove ecosystems in the Pacitan Coast, East Java, Indonesia
}

\author{
MUCHAMMAD SHOLIQIN ${ }^{1}$, PUTRI SEGI PRAMADANINGTYAS ${ }^{1}$, IVO SOLIKAH $^{\mathbf{1}}$, SARAH FEBRIYANTI $^{\mathbf{1}}$, \\ MARIYOTO DANANG PAMBUDI ${ }^{1}$, SALSA BERLIANI MAHARTIKA ${ }^{2}$, ALISA FAIDATUL UMAM ${ }^{2}$, NOR LIZA ${ }^{3}$, \\ AHMAD DWI SETYAWAN 1,4, \\ ${ }^{1}$ Department of Environmental Science, Faculty of Mathematics and Natural Sciences, Universitas Sebelas Maret. Jl. Jend. Urip Sumoharjo No. 179, \\ Surakarta 57128, Central Java, Indonesia. Tel.: +62-271-663375, `email: volatileoils@ gmail.com \\ ${ }^{2}$ Department of Environmental Science, Faculty of Mathematics and Natural Sciences, Universitas Negeri Semarang. J1. Raya Sekaran, Gedung D5 \\ Lantai 1, Kampus FMIPA Unnes, Gunung Pati, Semarang 50229, Central Java, Indonesia \\ ${ }^{3}$ Biodiversity Study Club, Department of Biology, Faculty of Mathematics and Natural Sciences, Universitas Sebelas Maret. Jl. Ir. Sutami No. 36A, \\ Surakarta 57126, Central Java, Indonesia \\ ${ }^{4}$ Biodiversity Research Group, Universitas Sebelas Maret. J1. Ir. Sutami 36A, Surakarta 57126, Central Java, Indonesia
}

Manuscript received: 4 December 2021. Revision accepted: 30 December 2021.

\begin{abstract}
Sholiqin M, Pramadaningtyas PS, Solikah I, Febriyanti S, Pambudi MD, Mahartika SB, Umam AF, Liza N, Setyawan AD. 2021. Analysis of the diversity and evenness of mangrove ecosystems in the Pacitan Coast, East Java, Indonesia. Intl J Bonorowo Wetlands 11: 84-94. Indonesia has a high mangrove diversity with 43 species of true mangrove plants. Mangrove grows along the coastline of Indonesia's islands, one of which is situated on the southern coast of Java. Pacitan, which belongs to the south coast of East Java and has $70,709 \mathrm{~km}$ of coastline, is an area with the potential to have diverse mangrove vegetation. The existence of mangroves plays a role in carbon sequestration and the stability of coastal ecosystems. This study aimed to determine the mangrove diversity and evenness index in the southern coast of Pacitan. This research was conducted on November 2021 in three locations, namely the Teleng Ria, Grindulu Estuary, and Siwil Beach. Data was collected using a plot of $10 \times 10 \mathrm{~m}^{2}$ for trees, $5 \times 5 \mathrm{~m}^{2}$ for saplings, and $2 \times 2 \mathrm{~m}^{2}$ for seedlings. The data obtained were analyzed using the Shannon Wiener and Evenness index to calculate the mangrove diversity and evenness value. There are 8 species of mangroves ( 7 species of major and 1 species of minor mangrove) and 2 species of associated mangroves, with the domination of Rhizophora stylosa. The Shannon Weiner diversity index shows that the mangrove diversity index in the research areas ranges from low to moderate. The Evenness Index presents that Teleng Ria Estuary possesses a high evenness value, indicating its stable mangrove condition.
\end{abstract}

Keywords: Diversity, evenness, mangrove ecosystem, Pacitan

\section{INTRODUCTION}

Mangroves have a high productivity role compared to other ecosystems, making the mangrove ecosystem essential for living things' lives. The characteristics of mangrove forests are also unique compared to other forest areas. This uniqueness can be seen in their habitat and diversity (Karimah 2017). Usually, mangroves can grow in muddy coastal wetlands found in tropical and subtropical areas (Hakim et al., 2017). In addition, mangroves can also live in lagoon areas, river estuaries that are inundated when the tide occurs or are free from inundation at low tide. Mangroves can adapt to high salt levels and have many physical, ecological, and economic (Alvareza and Leilani 2020). The benefits of mangroves in coastal areas are in the form of carbon sequestration, neutralizing the harmful pollutant materials, reducing approximately $50 \%$ of the strength of tsunami waves, protecting coastlines, and enriching coastal waters where they can be used as various flora and fauna habitats, and have the potential to ecotourism (Harahab and Setiawan 2017). The diverse functions of mangroves contribute to living things and support life (Konom et al. 2019).

The mangrove areas in the world reach $16,530,000$ ha, and Indonesia is one of the countries with the world's largest mangrove ecosystem, estimated at 3,489,140.68 ha along $95,181 \mathrm{~km}$ of coastline (Akbaruddin et al. 2020). The area of mangroves in Indonesia reaches $23 \%$ of the total mangroves in the world, and a total of $50 \%$ of mangroves in Asia are in Indonesia (Junialdi et al. 2019). Mangrove forest areas in Indonesia grow and develop throughout the Indonesian archipelago from Sumatra to Papua. It is estimated that there are 202 species of mangrove species that grow in mangrove forest areas in Indonesia, which consist of 89 tree species, 5 palm species, 19 climber species, 44 herb species, 44 epiphytic species, 1 species of ferns; it can also be classified as 43 species of true mangroves, and the other species are associated mangroves (Khairunnisa et al. 2020). However, according to Majid et al. (2016), the mangrove ecosystem in Indonesia is in a critical condition, namely experiencing damage which is predicted to be up to $68 \%$ or around 5.9 million hectares. The damage is due to human activities that make changes in the composition of mangroves, resulting in mangrove forests being unable to function, for example, the conversion of land functions to meet human needs (Ramena et al. 2020). Most of the damage occurred in the areas of Bali and Java (Eddy et al., 2015). Thus, mangrove 
areas in Indonesia currently require proper management (Ritohardoyo and Ardi 2014).

One of the mangrove areas is in Pacitan District, East Java, Indonesia. It is located in the southern coastal area of Java Island, and the topography of this district is dominated by hills (Mardika et al., 2020). The coastal area in this district consists of 26 villages originating from 7 subdistricts, with coastal areas having a slope of 0 to $2 \%$ and the coastal areas of Pacitan District having an area of about $4.36 \%$ of the total area of the district (BPS Kabupaten Pacitan). Pacitan coast faces directly to the open sea of the Indian Ocean, which has strong waves. Karst areas from the Southern Mountains dominate the coastal area. This district has a coastline of $70.709 \mathrm{~km}$, but generally, it is a steep beach, while on a sloping beach, it is dominated by white sand from coral. The district is fed only by small and short rivers, and the two largest rivers are the Grindulu River $(70 \mathrm{~km})$ and Lorog River $(60 \mathrm{~km})$ (BPS Pacitan 2021). The rainfall is high, the climate is C2-C3 type (Oldeman 1975), but because it is located in a karst area and the river flow is short, the sedimentation in the estuary is relatively limited and lacks nutrients. This condition causes the area for mangrove growth to be somewhat limited, and a unique mangrove ecosystem is formed according to these characteristics. For this reason, this research was conducted to find out more about mangroves in Pacitan, then to determine the mangrove diversity index and the evenness diversity index in the southern coast of Pacitan.

\section{MATERIALS AND METHODS}

\section{Study area}

This research was conducted in November 2021 and located along the Pacitan south coast, East Java, Indonesia
(Figure 1). Pacitan District is located between 7 92' - 8 29' $\mathrm{S}$ and $11090^{\prime}-11143^{\prime} \mathrm{E}$. In 2021, the air temperature was $26-29^{\circ} \mathrm{C}$; the average humidity was $23-27.5 \%$, the number of rainy days was 179 days with rainfall $841 \mathrm{~mm}^{3}$ (BPS Pacitan 2021). The locations were chosen because they have unique mangrove forests. This research data was obtained from three sampling points: the Teleng Ria Estuary, Grindulu Beach, and Siwil Beach. The coordinate of each location is presented in Table 1.

\section{Procedures}

Mangrove survey was conducted using 10 square plots in each station. Each plot was divided by $10 \times 10 \mathrm{~m}^{2}$ for the tree, $5 \times 5 \mathrm{~m}^{2}$ for sapling and pole, and $2 \times 2 \mathrm{~m}^{2}$ for seedling (Figure 2). The mangrove classification based on the growth level refers to Kasmadi (2015): seedling is the initial growing stage with less than $1,5 \mathrm{~m}$ height (i), the sapling is the stage with a height more than $1,5 \mathrm{~m}$ and less than $10 \mathrm{~cm}$ in diameter (ii), pole has a diameter range from 10 to $20 \mathrm{~cm}$ (iii); and tree category with a diameter above $20 \mathrm{~cm}$ (iv). The observation includes species identification within the square plot, the total number of mangrove species, a height, and DBH measurement of $10 \mathrm{~cm}$ above the still roots. Both assessments are used to differentiate the mangrove species into different growth stages. Furthermore, the measurement of abiotic factors, including temperature, salinity, and $\mathrm{pH}$, was also carried out at each observation location. For identification purposes, Rusila Noor et al. (1999) and Giesen et al. (2007) were used based analysis of morphological characters. Subsequently, key characters from unidentified species samples (e.g., flower and fruit) were taken and photographed for further identification in the Laboratory of Environment, Universitas Sebelas Maret, Surakarta, Indonesia.

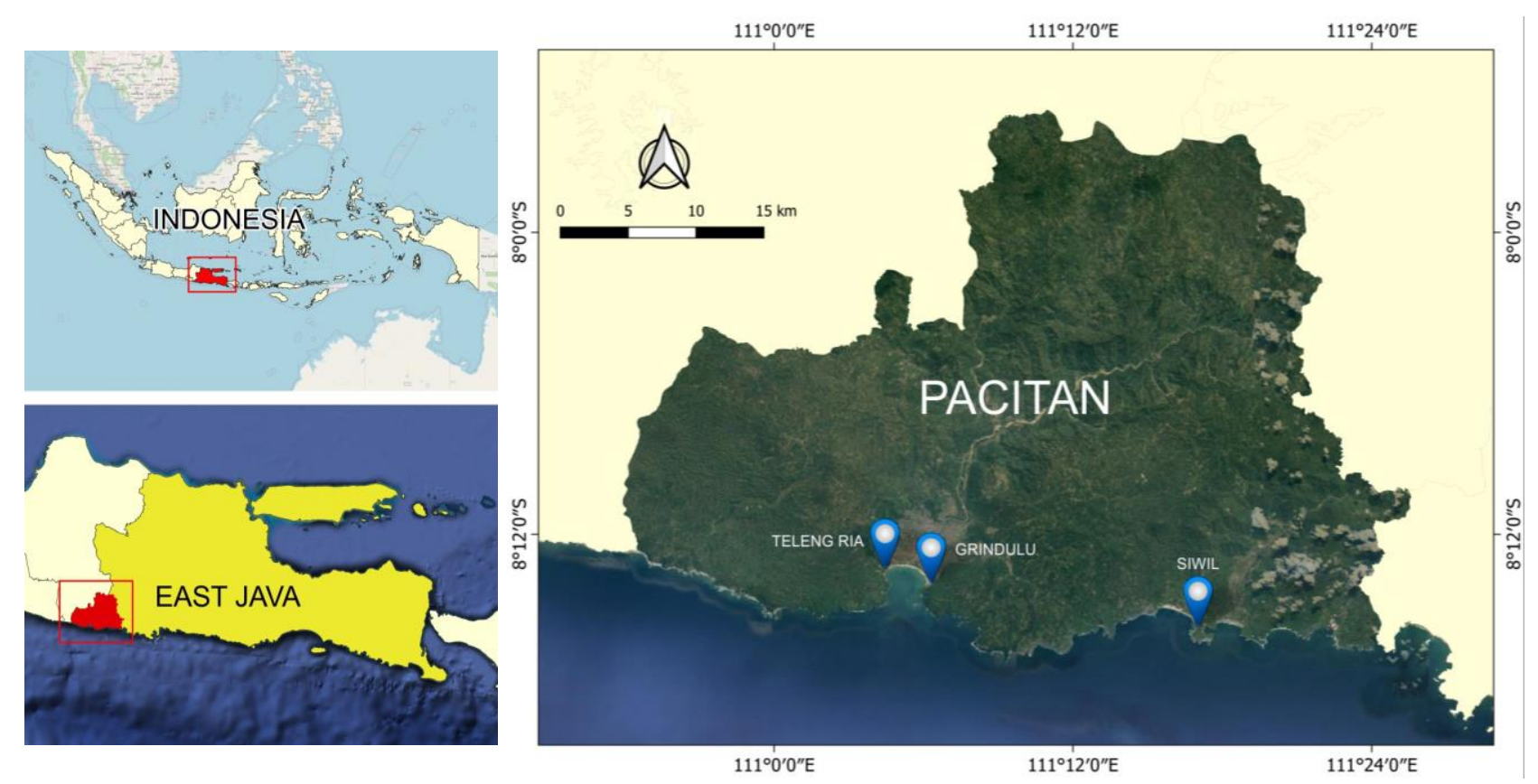

Figure 1. The sampling area is in Pacitan, East Java, Indonesia. (Location 1: Teleng Ria Estuary; location 2: Grindulu Beach; location 3: Siwil Beach) 
Table 1. Coordinate research stations

\begin{tabular}{llccl}
\hline Site & \multicolumn{1}{c}{ Location } & Coordinate point & $\begin{array}{c}\text { Estimation of mangrove } \\
\text { area width }\end{array}$ & $\begin{array}{c}\text { Characteristic of } \\
\text { substrate }\end{array}$ \\
\hline 1. & Teleng Ria Estuary & $8^{\circ} 13^{\prime} 17.0^{\prime \prime} \mathrm{S} 111^{\circ} 04^{\prime} 25.0^{\prime \prime} \mathrm{E}$ & $2183 \mathrm{~m}^{2}$ & Sandy, muddy \\
2. & Grindulu Beach & $8^{\circ} 13^{\prime} 50.4^{\prime \prime} \mathrm{S} 111^{\circ} 06^{\prime} 13.5^{\prime \prime} \mathrm{E}$ & $3917 \mathrm{~m}^{2}$ & Sandy, muddy \\
3. & Siwil Beach & $8^{\circ} 15^{\prime} 37.4^{\prime \prime} \mathrm{S} 111^{\circ} 17^{\prime} 00.1^{\prime \prime} \mathrm{E}$ & $1065 \mathrm{~m}^{2}$ & Sandy, rocky, muddy \\
\hline
\end{tabular}

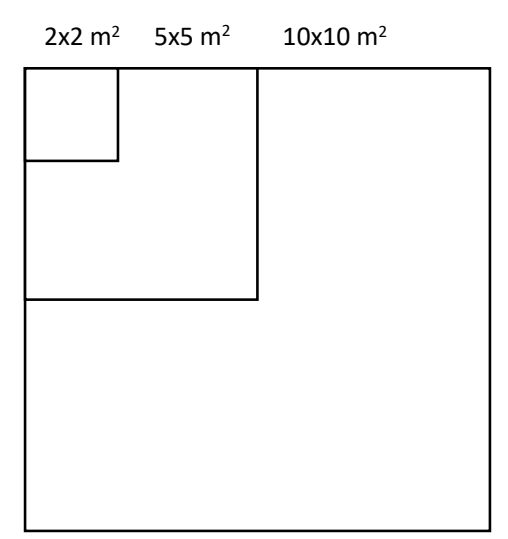

Figure 2. The square plot method for mangrove observation

\section{Data analysis}

Data analysis was carried out quantitatively using Microsoft Office Excel software. The following formulas are used to calculate the mangrove diversity and evenness index.

$$
H=-\sum \text { pi } \times \ln \text { pi }
$$

Where:

H' : Diversity index of Shannon-Wienner

$\mathrm{Pi}$ : The number of individuals of a species divided by the total number of species found

The criteria for the diversity index are:

$$
\mathrm{H}^{\prime}<1.5 \text { : low category }
$$$$
1.5<\mathrm{H}^{\prime}<3.5: \text { medium category }
$$

H’>3.5 : high category (Krebs 1989)

$$
E=\frac{H^{\prime}}{\ln (S)}
$$

Where:

$$
\begin{aligned}
& \mathrm{E} \quad \text { : Evenness index } \\
& \mathrm{H} \\
& \mathrm{S}
\end{aligned}
$$

With the following criteria: (i) E' $\leq 0.5$ : low uniformity, mangrove condition is depressed; (ii) $0.5<\mathrm{E}^{\prime} \leq 0.75$ : moderate uniformity, mangrove condition is less stable; (iii) $0.75<\mathrm{E}^{\prime} \leq 1$ : high uniformity, mangrove condition is stable (Krebs 2014).

\section{RESULTS AND DISCUSSION}

\section{Research area condition}

Mangrove abundance is hugely impacted by its habitat condition, including temperature, $\mathrm{pH}$, salinity, and substrate. Each mangrove develops a different range of tolerance levels to environmental factors. Based on the direct observation, the temperature in a range of $32-33^{\circ} \mathrm{C}$, while $\mathrm{pH}$ soil level in three research locations between 6 and 7. At the same time, the salinity was documented from 5 to 10 ppt. (Table 2). Regarding temperature, it can be fluctuated according to the observation time due to the sunlight effect. It has a significant impact on mangrove growth as the connection to the photosynthesis rate. Different ranges of temperature in mangrove ecosystems were shared by some research, including at $29-32^{\circ} \mathrm{C}$ in Mentawai Island (Rizal and Anna 2020), between 30$31,8^{\circ} \mathrm{C}$ in Torsiaje Jaya Village, Gorontalo (Rahim et al. 2017), and $24-31^{\circ} \mathrm{C}$ in North Coast of Jakarta (Hilmi et al. 2021). Those conditions are still acceptable for mangroves to grow well because the photosynthesis process will decrease dramatically if the temperature is more than $35^{\circ} \mathrm{C}$ (Kusmana 2010).

In terms of $\mathrm{pH}$, Teleng Ria Estuary and Siwil Beach had a similar value, when the highest level was shown in Grindulu River. These results are in the $\mathrm{pH}$ range for optimal mangrove species to thrive based on the Kai et al. (2012) experiment. It mentioned that Avicennia alba seedling would grow optimally in the $\mathrm{pH}$ level from 5.167.72. Additionally, research conducted by Nasrin et al. (2016) showed the highest percentage of germination on mangrove association occurred at $\mathrm{pH} \quad 0-10$ and then continued to decrease along with increasing $\mathrm{pH}$ level until no germination occurred at $\mathrm{pH} 25-35$.

Table 2. Abiotic factors in mangrove area in Pacitan District, Indonesia

\begin{tabular}{lccc}
\hline \multicolumn{1}{c}{ Research sites } & $\begin{array}{c}\text { Temperature } \\
\left({ }^{\circ} \mathbf{C}\right)\end{array}$ & $\mathbf{p H}$ & Salinity \\
\hline Teleng Ria Estuary & 33 & 6 & 5 \\
Grindulu River & 32 & 7 & 10 \\
Siwil Beach & 32 & 6,1 & 5 \\
\hline
\end{tabular}


Salt concentration in Grindulu River far exceeds the remaining locations, which shared the same value at $5 \mathrm{ppt}$. The site of Grindulu has a significant impact on this result as it is situated closest to the shore, causing saline water to enter the mangrove area periodically. Even though each mangrove has different sensitivity levels, as Elster (2000) proposed, Avicennia germinans was the most tolerant species in contrast to Rhizhopora mangle as the most sensitive mangrove. Still, a salinity level between 10-30 ppt serves the best condition for mangroves (Hilmi et al., 2021). Thus, the research locations in Pacitan have salinity value that is less supportive for mangrove development.

From the observation, the mangrove habitat in the Pacitan area is dominated by various sediments, including mud, sand, or both combinations. Like other abiotic factors, mangrove species have different preferences regarding the growth habitat. For instance, Avicennia is usually welldeveloped in the fine soil and sandy habitat, while sandy to a muddy substrate is suitable for Rhizophora and Sonneratia (Abubakar et al. 2020; Jalil et al. 2020). Furthermore, the type of sandy is correlated to the nutrient composition in a particular habitat. According to Adeney et al.'s (2016) study, it is mentioned that white sand is highly associated with nutrient scarcity and subsequently will impact the organism abundance in the area. In line with this, Siwil Beach is characterized by a white sandy habitat with soft soil in the inundation area.

\section{Mangrove species in Pacitan coastal areas}

The mangrove community of Pacitan consists of 10 species of mangrove, including seven species of the major component (Avicennia alba, Avicennia marina, Rhizophora stylosa, Rhizophora mucronata, Sonneratia caseolaris, Sonneratia alba, and Nypa fruticans), a species of minor component (Aegiceras corniculatum), and two species of mangrove associated (Derris trifoliata and Acanthus ilicifolious,). Those finding represent six families, including Acanthaceae, Arecaceae, Leguminosae, Lythraceae, Primulaceae, and Rhizophoraceae. Acanthaceae dominated the result consisting of three species, followed by Lythraceae and Rhizophoraceae that depicted by two species each (Table 3). This result shows that more major components have grown in Pacitan lately than the Setyawan et al. (2002) study that found two species ( $A$. alba and $S$. alba). However, that previous research managed to identify eight species of mangrove association.

The mangrove species grows in three sites of Pacitan District is higher than the result in mangrove forest situated in Pasarbanggi, Central Java and Torosiaje Jaya, Gorontalo, that only four species were found in each location (Rahim et al. 2017; Wicaksono and Muhdin 2015), and five species in Kedawang, Pasuruan (Isroni et al. 2019). In contrast, a more significant number were presented in various studies. For example, 24 mangrove species were identified in Segara Anakan (Hilmi et al. 2021), 14 species were reported to grow in Panjang Island, Jepara (Utami et al. 2017).

Moreover, Sudarmadji and Indarto (2011) was found 14 species of true mangrove (major and minor) in Banyuwangi District (Tl. Grajagan, Tl. Pangpang, Bengkak, Alas Buluh), 12 species from Situbondo (Buyunglugur Barat,
Buyunglugur Timur, Kendit, Panarukan), and 2 species from Jember (Kali Malang). Setyawan et al. (2005) was found 36 species of which 14 species of true mangrove was found in Demak District (Wulan, Sigrogol, Serang), 12 spesies of which 7 species of true mangrove was found in Jepara (Bulak, Teluk Awur), 14 species of which 5 species of true mangrove was found in Pati (Tayu, Juwana), 24 species of which 13 species of true mangrove was found in Rembang (Pecangakan, Pasar Bangi, Lasem), 24 species of which 6 species of true mangrove was found in Purworejo (Bogowonto, Ckrayasan, Lukulo), 16 species of which 7 species of true mangrove was found in Kebumen (Cingcingguling, Ijo), 36 of which 22 species of true mangrove was found in Cilacap (Bengawan, Serayu, Tritih, Motean, Muara Dua).

An impressive number of mangroves are listed in Katunggan, the Philippines, at 29 species, three listed as threatened species (Mangaoang and Flores 2019). Many aspects, including environmental factors, propagule types, and species competition, are considered a major role in the species distribution (Nakorn et al., 2018). Generally, districts on the north coast of Java have more mangrove species than the south coast (Setyawan 2005).

\section{Teleng Ria Estuary}

This station has a characteristic of sandy and soft soil as it is a riverbank area that leads directly to the Teleng Ria beach. This research identified seven kinds of mangrove grow in this location, including A. alba, A. marina, $S$. caseolaris, and $R$. stylosa in terms of major components, along with A. ilicifolious, $N$. fruticans, and D. trifoliata as associated species. The number of $A$. alba was much more significant than other species that accounted for 201 individuals (Table 3). According to Isroni et al. (2019), a big stem and the vast canopy provide advantages for the growth of $A$. alba, so they often reported dominating a habitat. Sedimentation also becomes a determining factor for mangrove regeneration and survival. This station belongs to the riverbank area; it contains rich organic sediment. In line with this, A. alba experienced a lower mortality rate in a habitat with sedimentation disturbance. However, the survival rate showed a declining trend if additional pressures were presented, such as water movement and flood (Balke et al., 2013). In this station, A. alba was reported to grow with a height range between 2 and 12 meters with a fruit-like-nut shape in green (Figure 3).

At this location, 110 individuals of $R$. stylosa were found, followed by $A$. marina, $S$. caseolaris, and $A$. ilicifolious in terms of true mangrove. Avicennia marina announced to have a broad salinity tolerance. In addition, a high salinity level triggers A. marina's seedling to grow significantly, but a lower salinity has no adverse impact on plant development (Cheng et al. 2020). Another fact is that A. marina also has a wide tolerance to metals content in soil by removing excess contamination substances in the plant body through the salt glands (Naidoo et al., 2014). However, apart from its ability, it is reported that A. marina should not be used as a phytoremediation agent. Its ability to remove accumulated metal is only temporary and will be released later. 
Table 3. The number of mangrove species and associations were found in Pacitan District, Indonesia

\begin{tabular}{llccc}
\hline \multirow{2}{*}{ Family } & \multirow{2}{*}{ Species } & \multicolumn{3}{c}{ Research sites (individuals) } \\
\cline { 3 - 5 } Acanthaceae & Avicennia alba & Teleng Ria Estuary & Grindulu River & Siwil Beach \\
& Avicennia marina & 201 & 6 & - \\
& Acanthus ilicifolious** & 42 & - & - \\
Arecaceae & Nypa fruticans & 25 & - & - \\
Leguminosae & Derris trifoliata** & 10 & - & - \\
Lythraceae & Sonneratia caseolaris & 32 & 30 & - \\
& Sonneratia alba & - & - & 7 \\
Primulaceae & Aegiceras corniculatum* & - & - & - \\
Rhizophoraceae & Rhizopora stylosa & 110 & - & 3 \\
& Rhizophora mucronata & - & - & \\
\hline
\end{tabular}

Note: *: Minor component; **: Association mangrove; -: not present

Avicennia marina was documented to occur in this station in a height range between 1 and 5 meters with a maximum DBH of $10 \mathrm{~cm}$. Similar to the first study location, muddy clay rich in organic substance becomes a characteristic of the riverbank area. However, it has been widely reported that sandy substrate is the preferred habitat for A. marina and leads to its dominance (Rizal and Anna 2020). The possibility of unsuitable substrate composition at this location makes $A$. marina mostly found at the seedling level.

Another species identified in Teleng Ria estuary was $S$. caseolaris, with 32 individuals. It grows at a height range between 1 and 7 meters with DBH size up to $26 \mathrm{~cm}$. This species is distinguished by upward-facing flower petals and red stamens (Figure 4). Sonneratia caseolaris fruiting and flowering stages were documented in this research. The fruit is green, round in shape, and contains many fruits. According to (Rahim and Bakar 2018), this fruit can live afloat in the water and help this species to disperse in the tide. This species usually thrives in the upstream estuarine area with deep muddy soil as the substrate (Tatongjai et al., 2021). Thus, the characteristic of that Teleng Ria estuary has, in fact, fit with $S$. caseolaris preferences.

Mangrove associates also identified with $N$. fruticans as the most frequently encountered species during the research. Nipa is the only palm that can survive in the mangrove region and has a morphological characteristic with compound leaves that elongate like coconut leaves. This species has a height between 3 and 5 meters. Habitat with a low to moderate salinity level and high turbidity allows N. fruticans to adapt (Lestari and Noor'an 2019; Theerawitaya et al. 2014). Derris trifoliata also grew in Teleng Ria estuary with 10 individuals. It has morphological characteristics of parallel leaves with pointed ends, white flowers clustered, and small petals. The air cavities within D. trifoliata's fruits help the species to float and spread in the tidal area (Raju and Kumar 2016). Both N. fruticans and $D$. trifoliate are only found on this site. The presence of associated mangroves supports populations in coastal areas (Rozak et al. 2020).

Physiologically, A. ilicifolious develop adaptation systems similar to plants that live in dry places, including salt glands and thick leaves (Hilal and Hilal 2019). The presence and dominance of this species in a particular area indicate ecosystem destruction (Irawanto et al., 2015). Furthermore, it also said that the accumulation of the wastes collected in the wetland areas is the habitat of this species as the main reason. In line with this statement, a study conducted by Wijayanti (2017) revealed that the heavy metal components that exceed the threshold were found in the Grindulu's downstream. In this research station, A. ilicifolious was documented in the seedling phase with a maximum height of only 1 meter. It is locally known as jeruju and is commonly used as a decorative plant due to its unique leaves shape. In addition, it is considered an herbal medicine that is widely used in traditional communities as it contains numerous secondary metabolites (Tan et al., 2016). Photographs of mangrove association are presented in Figure 5.

\section{Grindulu River}

The Grindulu River, as the second research location, is a muddy area where a mangrove planting program is being carried out by a non-government organization and was supported by the local authorities. This effort is insisted as a disaster management strategy for riverbank protection areas from flooding and erosion caused by overflowing rivers, especially in the rainy season (Utami and Luthfi 2019). Based on this research, four mangrove species were listed, consisting of A. alba, A. marina, S. caseolaris, and $R$. stylosa. As the data presented in Table 3, the number of $R$. stylosa far exceeds other species (195 individuals). Research conducted by Mayor et al. (2017) also obtained the same results where the family Rizophoraceae dominates the Mansuar Island, Raja Ampat. The reason is Rhizophoraceae can utilize solar energy, nutrients or minerals, and water to the maximum and has competitive properties compared to other species. However, Nasir and Yusmah (2007) reported that $R$. stylosa rarely exist in muddy locations and prefer to live in soil with sandy substrate. The difference result with this research is due to the planting program in the Grindulu riverbank area, causing these species to thrive even though mostly still in a seedling category. Still, $R$. stylosa is the best option for this program as it can prevent erosion in the coastal area (Nasir and Yusmah 2007).

Selecting mangrove species for reforestation, apart from considering the species function, the resistance of species 
with the habitat condition must also be considered. Sonneratia caseolaris was planted in the Grindulu river area to support the rehabilitation program. According to Githaiga et al. (2020), pneumatophores in Sonneratia help survive in poor conditions, such as inundation and flood. An insignificant number of $A$. alba and A. marina also found in this station indicates those species are not suitable for the habitat condition. This is supported by Nasir and Yusmah (2007) that Avicennia species can grow well in a sandy area.

\section{Siwil Beach}

Siwil Beach is a white sandy beach that faces directly to the Indian Ocean. This station was intended for mangrove restoration after being affected by heavy floods at the end of 2017 and as a prevention approach for seasonal flooding. Two major mangroves were identified in this location, namely $S$. alba and $R$. mucronata. Also found $A$. corniculatum is considered a minor mangrove. Interestingly, three species encountered in Siwil Beach were not identified in the other research locations. Sonneratia alba was the most abundant species, with 163 individuals were recorded. The height range that was documented in ranges from 1 to 6 meters. This species is characterized by white stamens and downward-facing flower petals (Figure 4).

Sonneratia alba belongs to pioneer species with a slowgrowing type and is considered a potential coastal restoration species (Balke et al., 2013; Pillai and Harilal, 2018). The white sandy beach that dominates this location is a suitable habitat for $S$. alba to grow and dominate the ecosystem. However, this species grows dwarf, probably due to limited nutrients. In Java, the growth of dwarf mangroves is rare, and it is interesting to investigate further regarding the physiological and environmental factors that influence it. Dharmawan and Pramudji (2020) mentioned that $S$. alba dominated the area with hard sand in Biak District. Conversely, R. mucronata was only listed at three individuals in Siwil Beach. Improper habitat leads to this result as this species tends to live in clay habitats. The same result was also suggested by Utami et al. (2017) that
$R$. mucronata grew poorly in Panjang Island, characterized by a sandy beach.

Aegiceras corniculatum, also known as pioneer species, was encountered in Siwil Beach. This species, which is considered to belong to the minor mangrove group (Tomlinson 1994), has a cylindrical, horn-like curved fruit that is light green to red when ripe. It grows as a scrub habitus with a height of approximately one meter (Figure 6). In Siwil Beach, A. corniculatum tends to thrive in the sandy-mud substrate in seasonal inundation areas. Like other mangrove plants, A. corniculatum has a unique adaptation to survive in mangrove conditions, namely salt secretion and crypto-vivipary (Feng et al., 2021). The increase in soil salinity triggers increasing salt secretion from the A. corniculatum's leaves to remove salt accumulation in the plant body (Jayatissa et al., 2006). Furthermore, the crypto-vivipary reproductive system allows the embryo to penetrate the seed coat but cannot penetrate the fruit wall before being in a favorable environment (Elmqvist and Cox 1996; Shi et al. 2005; Tomlinson 2016). This reproductive system enables mangroves to reproduce, which is more stable and adaptive to unfavorable conditions.

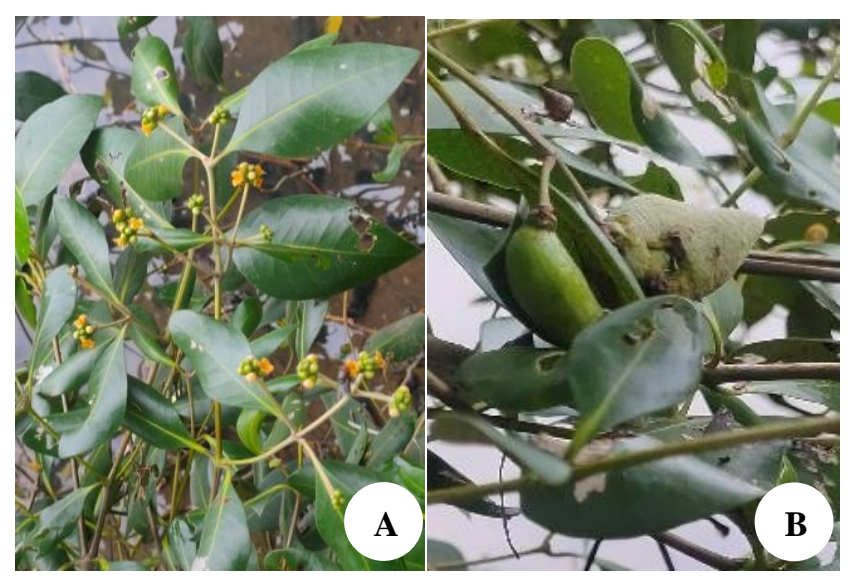

Figure 3. Avicennia alba flower (A) and fruit (B) from the southern coast of Pacitan, East Java, Indonesia

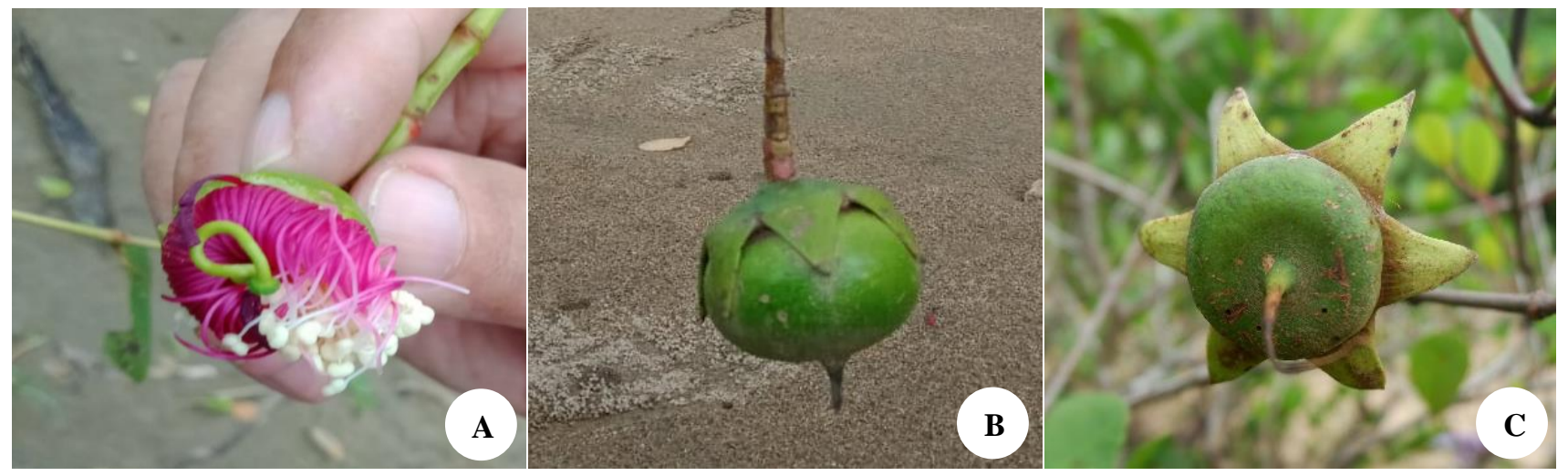

Figure 4. Lythraceae family in the southern coast of Pacitan, East Java, Indonesia. A-B. Flower and fruit of Sonneratia caseolaris. C. Fruit of Sonneratia alba 


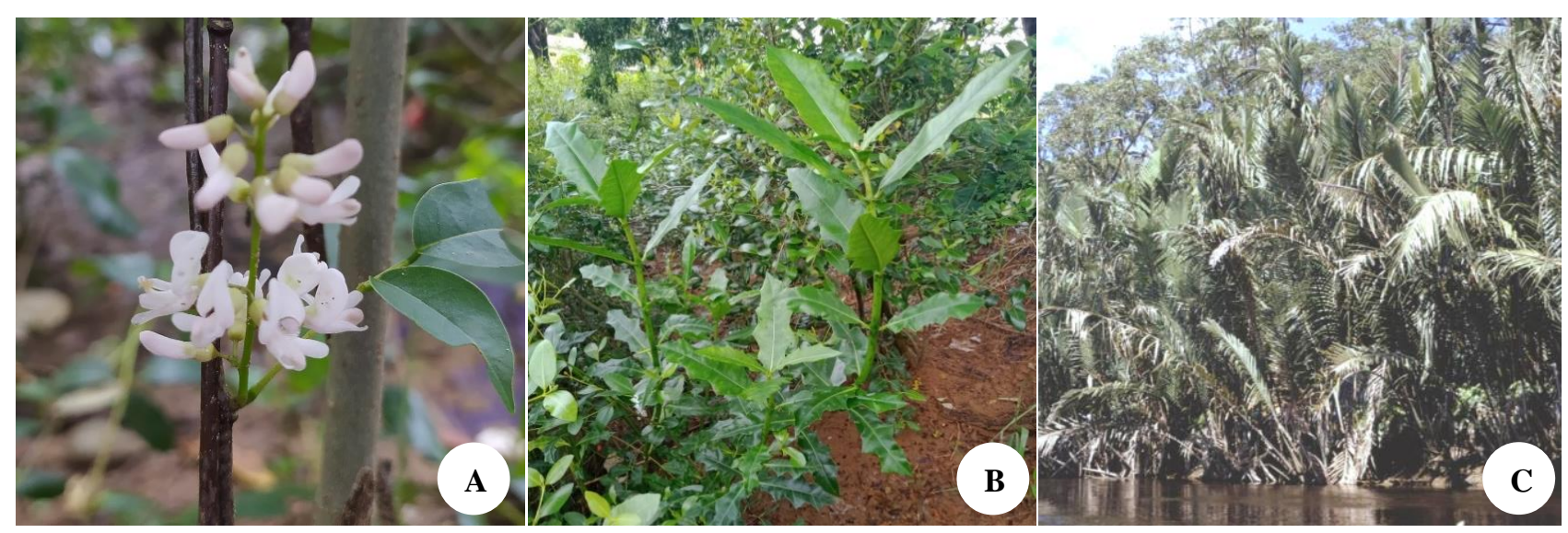

Figure 5. Mangrove association in the southern coast of Pacitan, East Java, Indonesia. A. Derris trifoliate; B. Acanthus ilicifolious; C. Nypa fruticans (Source: Plants of the World Online)

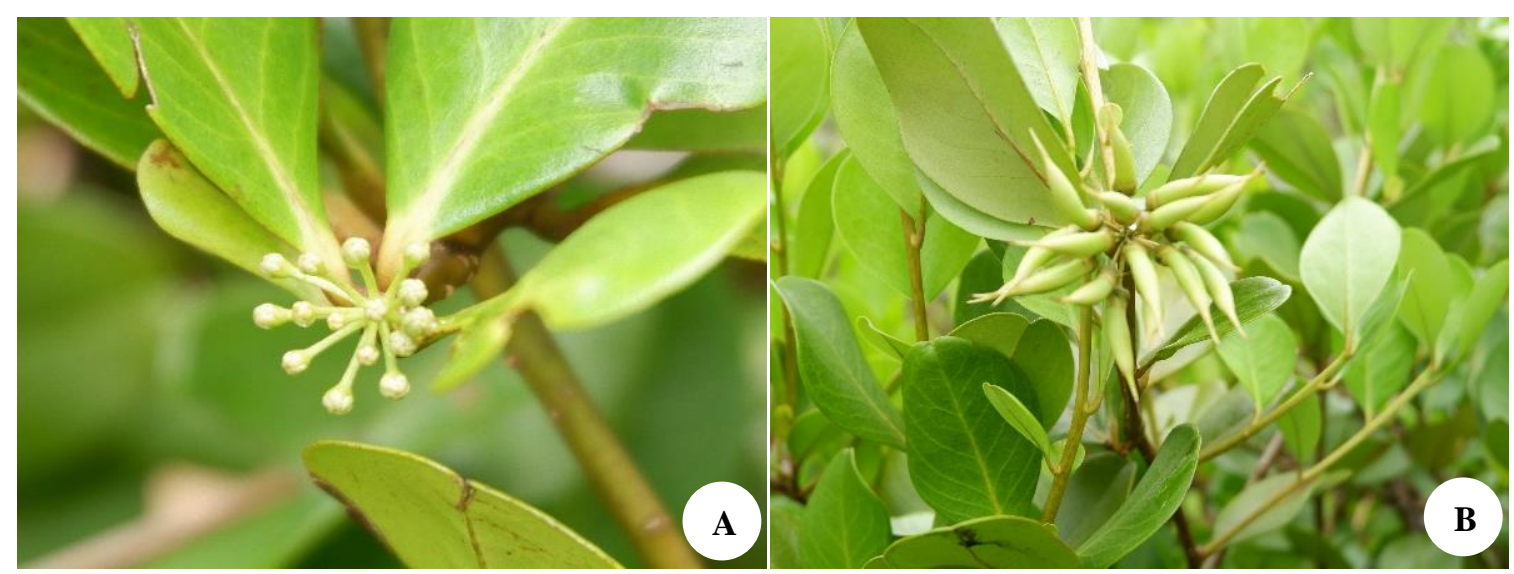

Figure 6. Aegiceras corniculatum flower (A) and fruit (B) in the southern coast of Pacitan, East Java, Indonesia

\section{Diversity of mangrove species}

The data obtained were analyzed using the ShannonWiener equation. Table 4 shows that Teleng Ria Estuary has the highest diversity index and is categorized as a medium group. In contrast, both Grindulu River and Siwil Beach belong to low categories. A low diversity status in a particular area indicates an unstable condition, mainly caused by natural and anthropogenic stress (Sreelekshmi et al., 2020). In Pacitan, natural disturbance seems to be the major factor driving the low diversity index rather than the human factor. Grindulu River usually experiences seasonal flooding and erosion, making mangrove species struggle to survive. In addition, this location has functioned as an aquaculture and ecotourism spot, making lots of people access this area. At the same time, Siwil Beach also experienced a massive flood years ago, leading to the loss of the majority of mangrove species. In addition to this, the intense domination of some species also makes the declining value of the diversity index. In this case, $R$. stylosa and $S$. alba had significant colonization numbers in Grindulu River and Siwil Beach, respectively.

On the other hand, the diversity index in Teleng Ria Estuary valued 1,52. The probable reasons are the accessibility and the wide area it has. The substrate of this location is dominated by deep mud. Thus, a proper tool (e.g., boots) is required to reach it. That condition enables mangrove species to grow well because they witness less disturbance from humans. Another thing is this area has a vast mangrove forest, and numerous species can be found here. The same result was also proposed by Poedjirahajoe et al. (2019) that the mangrove forest size heavily influences the diversity index.

Regarding growth stages in each location, it can be seen in Figure 7. Data of mangrove growth stages were obtained from height and DBH calculation, then adjusted according to the criteria proposed by Kasmadi (2015). The seedling phase dominated the Grindulu station because still in the process of planting. This also explains a small number of poles and trees there, as the mangrove is still in the regeneration stage. On the other hand, mangroves in the sapling phase are abundantly found in Teleng Estuary. The mangrove individuals grew naturally in some spots, indicated by the uneven composition. Furthermore, most mangroves are at pole level and are rarely found in tree stage in Siwil Beach. The massive flood could be the reason because it swept away the mangrove plants, and the remaining species still keep growing to reach the pole stage. Moreover, the local's effort to conduct reforestation was demonstrated in the seedling stage recorded, even not as significant as other locations, due to the impact of 
seasonal flooding. A similar result was proposed in Nicobar Island, that species regrowth had been conducted after tsunami causing mangrove species and habitat loss (Nehru and Balasubramanian 2018).

Understanding mangrove growth level is necessary to know the regeneration status in a particular wetland ecosystem. Regeneration condition is essential to determine the success of mangrove planting and reforestation. Such as proposed by Utami et al. (2017), a successful regeneration process is indicated by seedling $>$ sapling $>$ tree. Moreover, it can also be used to determine the age of mangrove ecosystems, such as Sudarmadji and Indarto's (2011) observation, which states that the age of mangrove forests in Banyuwangi is still relatively young to the absence of tree phase. From those statements, it can be seen that the Pacitan mangrove areas have a poor regeneration process because of the minimal number of seedlings in each area, with Grindulu River as an exception. The planting program in this location has a profound impact on regeneration progress with the abundance of seedling and sapling. In addition, the mangrove areas in Pacitan are considered still at an early age of development as the minimal number of trees in each location. The constant natural disturbance prevents mangroves from developing to further stages; thus, the planting program should be encouraged to preserve the sustainability of mangrove forests.

\section{Evenness of mangrove species}

The evenness index in this study ranged from 0,23-0,78 (Table 5). Teleng Ria Estuary had the most significant evenness value, while Siwil Beach and Grindulu River belonged to the low category. A high evenness index in Teleng Ria indicated that it has diverse mangroves with relatively the same proportion of individuals. On the other hand, the domination of certain species in Siwil Beach and
Grindulu River makes the evenness value are classified into low. In addition, a high value also means that the mangrove ecosystem in Teleng Ria is considered stable, unlike the others that have a depressed condition. Some factors causing a low evenness are geological, anthropocentric, weather, and sustainable conservation systems (Sannigrahi et al. 2020). The dominance of several mangrove species that tend to cluster in the southern coastal area of Pacitan makes the evenness index low. In line with Farista and Virgota's (2021) research, the value of the individual evenness index of mangroves in the Cendi Manik area, Sekotong, West Lombok is low due to the dominance of certain species in the community.

\section{The threat of mangrove species}

Two major threats that lead to mangrove forest destruction in Indonesia are human and natural factors. Generally, the former is the dominant cause, whether the latter is considered an inevitable agent that can cause severe impact.

In Pacitan, the natural threat to mangroves is caused by floods and a high tide. However, its location directly connected to the Indian Ocean makes Pacitan highly prone to high and strong waves, leading to erosion and coastal destruction (Utami and Luthfi 2019). In addition, many studies mentioned the tsunami prediction in Pacitan caused by the Eurasian and Indo-Australian plate collisions (Jamilah et al., 2021). Pulau Dua, Banten also has a similar condition that moderate waves significantly impact mangrove species (Vitasari 2015). Meanwhile, during the past 40 years, extreme weather events, biological invasions, and insect outbreaks were major natural factors that contributed to mangrove forest degradation in Guangxi (Jia et al. 2014).

Table 5. Evenness Index of mangrove and associated mangrove in the southern coast of Pacitan, East Java, Indonesia
Table 4. Diversity Index of mangrove and associated mangrove in the southern coast of Pacitan, East Java, Indonesia

\begin{tabular}{|c|c|c|c|c|c|}
\hline Location & Diversity index & Category & Location & Evenness index & Category \\
\hline Teleng Ria Estuary & 1.52 & Medium & Teleng Ria Estuary & 0.78 & High \\
\hline Grindulu River & 0.57 & Low & Grindulu River & 0.41 & Low \\
\hline Siwil Beach & 0.26 & Low & Siwil Beach & 0.23 & Low \\
\hline
\end{tabular}
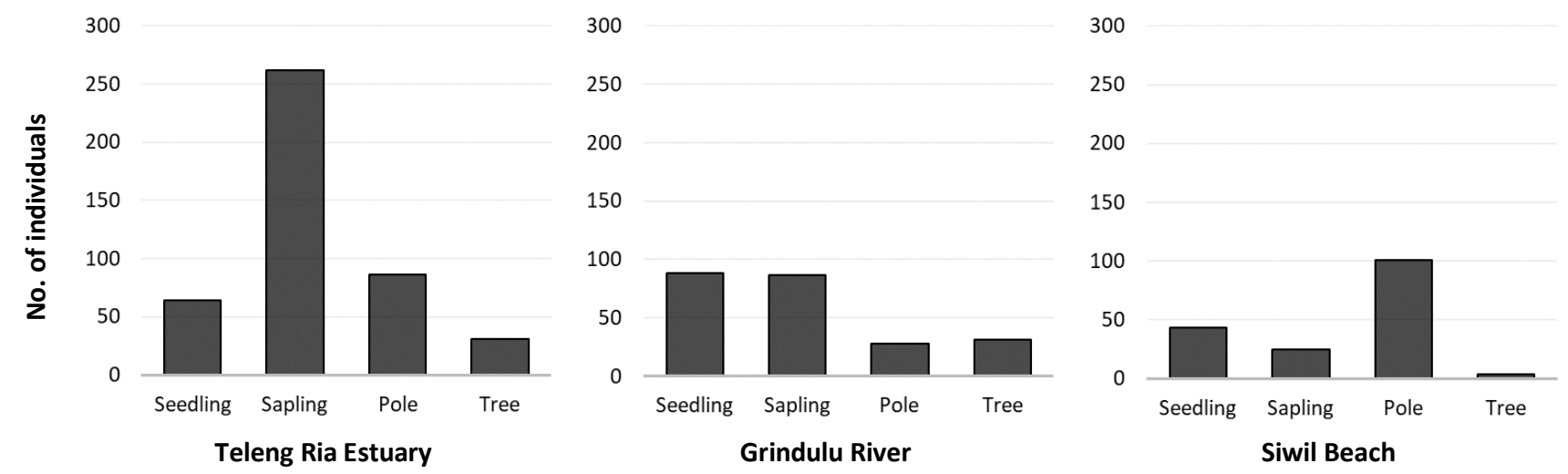

Figure 7. The number of mangrove species in four growth stages in the southern coast of Pacitan, East Java, Indonesia, i.e., Teleng Ria Estuary (left), Grindulu River (middle), and Siwil Beach (right) 
Human activities (anthropogenic) provide the most significant contribution to the destruction of mangrove forests in Indonesia. Conversion of mangrove forests for fisheries, plantations, agriculture, salt ponds, settlements, industry, agriculture, forest logging (legal logging and illegal logging), and mining is the principal anthropogenic activity that causes degradation and loss of mangrove forests (Ilman et al. 2011). However, the local communities in Pacitan show a great effort to preserve the mangrove ecosystem. It is indicated by their participation in mangrove planting with the local government and NGOs. However, inconsistency and unsustainability in maintaining the mangrove ecosystem cause the condition of the Pacitan mangrove are not as expected. Thus, making a tourism destination based on mangrove forests in the Grindulu area is expected to trigger residents to contribute more because they benefit from the economic side.

Although Indonesia has the highest global average above-ground biomass (AGB) of mangrove forests in the world (729,075,000 tons), Indonesia is one of the countries with the highest rate of mangrove forest loss also high (Hutchison et al. 2013). The condition of mangrove forests in Indonesia continues to experience damage and a reduction in the area, with the speed of destruction reaching $530,000 \mathrm{ha} /$ year. In contrast, the rate of increase in mangrove rehabilitation that can be realized is still much slower than the rate of destruction, which is only around $1,973 \mathrm{ha} /$ year.

The conversion of mangrove forests into aquaculture/pond land and agriculture is the leading cause of mangrove forest degradation in Indonesia. Ilman et al. (2011) and Eong (1995) in Hamzah and Setiawan (2010) argue that anthropogenic activities in the form of fisheries, plantations, agriculture, salt ponds, settlements, industry, logging (legal logging and illegal logging), and mining are the main factors of degradation and loss of mangrove forests in Indonesia. Meanwhile, Kustanti et al. (2012) argue that more than $50 \%$ of mangrove forests are degraded or lost due to several factors, such as the conversion of mangrove forests for fisheries, urbanization, oil pollution, and industrial waste lack of public awareness (Hutchison 2013).

To conclude, mangrove species in Pacitan are considered low to moderate diversity, and Teleng Ria has a high evenness index. Therefore, further management involving local communities and stakeholders is needed to improve mangrove sustainability in Pacitan.

\section{REFERENCES}

Abubakar S, Subur R, Malik FR, Akbar N. 2020. Damage level and area suitability of mangrove in small island Indonesia. IOP Conf Ser: Earth Environ Sci 584: 012037. DOI: 10.1088/17551315/584/1/012037.

Adeney JM, Christensen NL, Vicentini A, Cohn-Haft M. 2016. Review: White-sand ecosystems in Amazonia. Biotropica 48 (1): 7-23. DOI: 10.1111/btp. 12293.

Akbaruddin IP, Sasmito B, Sukmono A. 2020. Analisis Kolerasi Lulusan Kawasan Mangrove terhadap Perubahan Garis Pantai dan Area Tambak (Studi Kasus: Wilayah Pesisir Kabupaten Demak. Jurnal Geodesi Undip 9 (2): 217-226. [Indonesian]
Alvareza M, Leilani I. 2020. Community structure of the mangrove forest in the tourism area of Pariaman City West Sumatra. Bioscience 4 (1): 62-72. DOI: 10.24036/0202041108192-0-00.

BPS Kabupaten Pacitan. 2021. Kabupaten Pacitan dalam angka 2021. BPS Kabupaten Pacitan, Pacitan. https://pacitankab.bps.go.id/. [Indonesian]

Balke T, Webb EL, van den Elzen E, Galli D, Herman PMJ, Bouma TJ. 2013. Seedling establishment in a dynamic sedimentary environment: a conceptual framework using mangroves. J Appl Ecol 50 (3): 740747. DOI: 10.1111/1365-2664.12067.

Cheng H, Inyang A, Li CD, Zhou YW, Wang YS. 2020. Salt tolerance and exclusion in the mangrove plant Avicennia marina in relation to root apoplastic barriers. Exotoxicology. DOI: 10.1007/s10646-02002203-6.

Dharmawan IWE, Pramudji. 2020. Mangrove community structure in Papuan small islands, case study in Biak District. IOP Conf Ser: Earth Environ Sci 550: 012002. DOI: 10.1088/1755-1315/550/1/012002.

Eddy S, Mulyana A, Ridho MR, Iskandar I. 2015. Dampak aktivitas antropogenik terhadap degradasi hutan mangrove di Indonesia. Jurnal Lingkungan dan Pembangunan 1 (3): 240-254. [Indonesian]

Elmqvist T, Cox PA. 1996. The evolution of vivipary in flowering plants. Oikos 77: 3-9. DOI: 10.2307/3545579.

Elster C. 2000. Reasons for reforestation success and failure with three mangrove species in Colombia. For Ecol Manag 131: 201-214. DOI: 10.1016/S0378-1127(99)00214-5.

Farista B, Virgota A. 2021. The assessment of mangrove community based on vegetation structure at Cendi Manik, Sekotong District, West Lombok, West Nusa Tenggara. J Trop Biol 21 (3): 1022-1029.

Feng X, Li G, Xu S, Wu W, Chen Q, Shao S, Liu M, Wang N, Zhong C, He Z, Shi S. 2021. Genomic insights into molecular adaptation to intertidal environments in the mangrove Aegiceras corniculatum. New Phytol 231 (6): 2346-2358. DOI: 10.1111/nph.17551.

Giesen W, Wulffraat S, Zieren M, Scholten L. 2007. Mangrove Guidebook Southeast Asia. RAP Publication, Bangkok.

Githaiga MN, Kotut, K, Kariuki F, Kairo JG. 2020. Structure and biomass accumulation of natural mangrove forest at Gazi Bay, Kenya. Bonorowo Wetl 10 (1): 18-32. DOI: 10.13057/bonorowo/w100102.

Hakim L, Siswanto D, Nakagoshi N. 2017. Mangrove conservation in East Java: the ecotourism development perspectives. J Trop Life Sci 7 (3): 227-285. DOI: 10.11594/jtls.07.03.14.

Harahab N, Setiawan. 2017. Suitability Index of Mangrove Ecotourism in Malang Regency. ECSOFiM: J Econ Soc Fish Mar 4 (2): 153-165. DOI: 10.21776/ub.ecsofim.2017.004.02.05.

Hilal F, Hilal S. 2019. A study on morphological and anatomical features of Acanthus ilicifolius L. and Excoecaria agallocha L. selected from Ayiramthengu of Kollam district, Kerala. Pharm Innov J 8 (6): 507511.

Hilmi E, Sari LK, Cahyo TN, Muslih, Mahdiana A, Samudra SR. 2021. The affinity of mangrove species using association and cluster index in North Coast of Jakarta and Segara Anakan of Cilacap, Indonesia. Biodiversitas 22 (7): 2907-2918. DOI: 10.13057/biodiv/d220743.

Hutchison J, Manica A. Swetnam R, Balmford A, Spalding M. 2013. Predicting global patterns in mangrove forest biomass. Conserv Lett 7 (3): 233-240.

Ilman M, Wibisono ITC, Suryadiputra INM. 2011. State of the art information on mangrove ecosystems in Indonesia. Wetlands International-Indonesia Programme. Bogor, Indonesia.

Irawanto R, Ariyanti EE, Hendrian R. 2015. Jeruju (Acanthus ilicifolius): Biji, perkecambahan dan potensinya. Pros Sem Nas Masy Biodiv Indon 1 (5): 1011-1018. DOI: $10.13057 / \mathrm{psnmbi} / \mathrm{m010509.}$ [Indonesian]

Isroni W, Islamy RA, Musa M, Wijanarko P. 2019. Short communication: Species composition and density of mangrove forest in Kedawang Village, Pasuruan, East Java, Indonesia. Biodiversitas 20 (6): 20854722. DOI: $10.13057 /$ biodiv/d200626.

Jalil AR, Malik A, Nurdin N, Saru A. Yunus I. 2020. Assessment of seawater level, inundation duration, and substrate elevation for mangrove rehabilitation program in the Spermonde Archipelago South Sulawesi Indonesia. Intl J Conserv Sci 11 (4): 1115-1126.

Jamilah Z, Widodo A, Ariyanti N. 2021. Mapping tsunami hazard levels in Pacitan beach using remote sensing methods. J Mar-Earth Sci Technol 2 (1). DOI: 10.12962/j27745449.v2i1.64.

Jayatissa LP, Weerakkody WAT, Dissanayake NP. 2006. A study of salt secretion by mangroves of Rekawa Lagoon, Sri Lanka. Ruhuna J Sci 1: 1-15. DOI: 10.4038/rjs.v1i0.61. 
Junialdi R, Yonariza A, Arbain. 2019. Economic valuation of mangrove forest in Apar Village Pariaman City West Sumatra. Jurnal Analisis Kebijakan Kehutanan $16 \quad$ (2): 117-132. DOI: 10.20886/jakk.2019.16.2.117-132. [Indonesian]

Kai LZ, Peng GNH, Min GM, Ken LTY. 2012. Investigating the effect of soil $\mathrm{pH}$ on the germination of Avicennia alba seedlings. Nature Society, Singapore.

Karimah. 2017. Peran ekosistem hutan mangrove sebagai habitat untuk organisme laut. Jurnal Biologi Tropis. 17 (2): 51-58. DOI: 10.29303/jbt.v17i2.497. [Indonesian]

Kasmadi D. 2015. Komposisi dan struktur jenis pohon di hutan produksi terbatas Ake Oba-Tanjung Wayamli-Ake Kobe. COCOS 6 (13): 1-8. [Indonesian]

Khairunnisa C, Thamrin E, Prayogo H. 2020. Keanekaragaman jenis vegetasi mangrove di Desa Dusun Besar Kecamatan Pulau Maya Kabupaten Kayong Utara. Jurnal Hutan Lestari 8 (2): 325-336. DOI: 10.26418/jhl.v8i2.40074. [Indonesian]

Konom NH, Cabuy RL, Wanma AO. 2019. Damaging area identification of mangrove forest as a result of antropogenic activities in Airtiba, District of Kaimana. Jurnal Kehutanan Papuasia 5 (2): 153-163. DOI 10.46703/jurnalpapuasia.Vol5.Iss2.148. [Indonesian]

Krebs JC. 1989. Ecological Methodology. Wm. C. Brown Publisher, Dubuque.

Krebs JC. 2014. Ecological Methodology $3^{\text {rd }}$ ed. Addison Welsey, United States of America.

Kusmana C. 2010. Respon mangrove terhadap perubahan iklim global: aspek biologi dan ekologi mangrove. Lokakarya Nasional Peran Mangrove dalam Mitigasi Bencana dan Perubahan Iklim. KKP, Jakarta, 14-15 Des 2010. [Indonesian]

Kustanti A, Nugroho B, Darusman D, Kusmana C. 2012. Integrated management of mangroves ecosystem in Lampung Mangrove Center (Lmc) East Lampung District, Indonesia. J Coast Develop 15 (2): 209-216.

Lestari NS, Noor'an RF. 2019. Population density and habitat characteristics of Nipa fruticans in degraded mangrove ecosystem (Case study in Mahakam Delta, East Kalimantan). J Wetl Environ Manag 7 (1): 50-59. DOI: 10.20527/jwem.v7i1.193.

Majid I, Muhdar MHIA, Rohman F, Syamsuri I. 2016. Konservasi hutan mangrove di pesisir pantai Kota Ternate terintegrasi dengan kurikulum sekolah. Jurnal Bioedukasi 4 (2): 488-496. [Indonesian]

Mangaoang CC, Flores AB. 2019. Inventory of mangroves in Katunggan Coastal Eco-Park, Sultan Kudarat Province, the Philippines. Bonorowo Wetl 9 (2): 59-64. 64. DOI: 10.13057/bonorowo/w090202.

Mardika B, Utami S, Widiyanto J. 2020. Identifikasi keanekaragaman gastropoda sebagai bioindikator kualitas air sungai Nogosari Pacitan Symbiosis V. National Seminar Proceedings. [Indonesian]

Mayor, Troce, Herny EI, Simbala S, Koneri R. 2017. The biodiversity of mangrove in the Mansuar Island Raja Ampat District West Papua Province. Jurnal Bios Logos 7 (2): 41-48. DOI: 10.35799/jbl.7.2.2017.18576. [Indonesian]

Mingming J, Zongming W, Yuanzhi Z, Chunying R, Kaishan S. 2014 Landsat-based estimation of mangrove forest loss and restoration in Guangxi Province, China, influenced by human and natural factors. J Selected Topics Appl Earth Observ Remote Sens 8 (1): 311-323. DOI: $10.1109 /$ JSTARS.2014.2333527

Momo LOH, Rahayu WOS. 2018. Analysis of Mangrove Fores Vegetation in Wambona Village, South Wakorumba District, Muna District, Indonesia. Akuatikisle 2 (1): 10-16. DOI: 10.29239/j.akuatikisle.2.1.10-16. [Indonesian]

Naidoo G, Hiralal T, Naidoo Y. 2014. Ecophysiological responses of the mangrove Avicennia marina to trace metal contamination 209: 63-72. DOI: 10.1016/j.flora.2013.10.003.

Nakorn NW, Chanchaw W, Penprapai P, Chanchaw S. 2018. Diversity and evenness of mangrove trees in Thasala, Sichon, and Pakpaneang District, Nakhon Si Thammarat Province, Thailand. Intl J Agric Technol 14 (3): 333-340.

Nasir HM, Yusmah MYS. 2007. Distribution of Rhizophora stylosa in peninsular Malaysia. J Trop For Sci 19 (1): 57-60.

Nasrin S, Hossain M, Alam R, Abdullah SMR, Saha S, Siddique MRH. 2016. Germination traits of Millettia pinnata (L.) in response to salinity. Glob J Bot Sci 4: 46-51. DOI: 10.12974/2311858X.2016.04.01.6.

Nehru P, Balasubramanian P. 2018. Mangrove species diversity and composition in the successional habitats of Nicobar Islands, India: A post-tsunami and subsidence scenario. For Ecol Manag 427: 70-77. DOI: 10.1016/j.foreco.2018.05.063.
Oldeman LR. 1975. Agroclimatic Map of Java and Madura. Central Research Institute of Agriculture, Bogor, Indonesia.

Pillai NG, Harilal CC. 2018. Evaluation of the growth sustaining attributes of Sonneratia alba $\mathrm{Sm}$. for strategic afforestation protocols. Intl $\mathrm{J}$ Basic Appl Res 8 (9): 626-634.

Poedjirahajoe E, Sulistyorini IS, Komara LL. 2019. Species diversity of mangroves in Kutai National Park, East Kalimantan, Indonesia. Biodiversity 20 (12): 3641-3646. DOI: 10.13057/biodiv/d201224.

Rahim AC, Bakar MFA. 2018. Pidada-Sonneratia caseolaris. Exotic Fruits. Academic Press, NY. DOI: 10.1016/B978-0-12-8031384.00043-5.

Rahim S, Baderan DWK, Hamidun MS. 2017. The density, composition, and mangrove forest habitat in coastal areas of Torosiaje Jaya Village, Gorontalo, Indonesia. Bonorowo Wetl 7 (1): 38-42. DOI: 10.13057/bonorowo/w070108.

Raju AJS, Kumar R. 2016. Pollination ecology of Derris trifoliata (Fabaceae), a mangrove associate in Coringa Mangrove Forest, Andhra Pradesh, India. J Threatened Taxa 8 (5): 8788-8796. DOI: 10.11609/jott.2277.8.5.8788-8796.

Ramena GO, Wuisang FOP. 2020. Activity effect community against mangrove ecosystems in Mananggu District. Jurnal Spasial 7 (3): 343-351. [Indonesian]

Ritohardoyo SG, Ardi SGB. 2014. Arahan Kebijakan Pengelolaan Hutan Mangrove: Kasus Pesisir Kecamatan Teluk Pakedai, Kabupaten Kubu Raya, Propinsi Kalimantan Barat. Geography Journal 3 (2): 83-94. [Indonesian]

Rizal A, Anna Z. 2020. The effect on mangrove density with sediment transport rate in Sikakap Coastal Area of Mentawai Island District, West Sumatera Province, Indonesia. World Sci News 146: 202-214.

Rozak AH, Astutik S, Mutaqien Z, Sulistyawati E, Widyatmoko, D. 2020. Effectiveness of use of three diversity index in forest community analysis: a case study in Gunung Gede Pangrango National Park, Indonesia. J For Res Nat Conserv 17 (1): 35-47.

Rusila-Noor Y, Khazali M, Suryadiputra INN. 1999. Panduan Pengenalan Mangrove di Indonesia. PHKA/WI-IP, Bogor. [Indonesian]

Sannigrahi S, Zhang Q, Pilla F, Joshi PK, Basu B, Keesstra S, Sen S. 2020. Responses of ecosystem services to natural and anthropogenic forcings: A spatial regression based assessment in the world's largest mangrove ecosystem. Sci Tot Environ 715: 137004. DOI: 10.1016/j.scitotenv.2020.137004.

Setyawan AD. 2005. Keanekaragaman Tumbuhan Mangrove di Pantai Utara dan Selatan Jawa Tengah [Thesis], Universitas Sebelas Maret, Surakarta. [Indonesian]

Setyawan AD, Indrowuryatno, Wiryanto, Winarno K, Susilowati S. 2005. Mangrove plants in coastal area of Central Java: 1. Species diversity. Biodiversitas 6 (2): 90-94. DOI: 10.13057/biodiv/d060204.

Setyawan AD, Susilowati, Wiryanto. 2005. Relics habitat of mangrove vegetation in south coast of Java. Biodiversitas 3 (2): 242-256. DOI: 10.13057/biodiv/d030206.

Shi S, Huang Y, Zeng K, Tan F, He H, Huang J, Fu Y. 2005. Molecular phylogenetic analysis of mangroves: independent evolutionary origins of vivipary and salt secretion. Mol Phylogen Evol 34 (1): 159-166. DOI: 10.1016/j.ympev.2004.09.002.

Sreelekshmi S, Nandan SB, Kaimal SV, Radhakrishnan CK, Suresh VR. 2020. Mangrove species diversity, stand structure and zonation pattern in relation to environmental factors - A case study at Sundarban delta, east coast of India. Reg Stud Mar Sci 101111. DOI: 10.1016/j.rsma.2020.101111.

Sudarmadji, Indarto. 2011. Identifikasi lahan dan potensi hutan mangrove di bagian timur Propinsi Jawa Timur. Bonorowo Wetl 1 (1): 31-36. DOI: 10.13057/bonorowo/w010104. [Indonesian]

Tan D, Jiang C, Tao V. 2016. Chemical constituents of Acanthus ilicifolius. Chem Nat Compounds 52 (5): 951-952. DOI: 10.1007/s10600-016-1830-1.

Tatongjai S, Kraichak E, Kermanee P. 2021. Comparative anatomy and salt management of Sonneratia caseolaris (L.) Engl. (Lythraceae) grown in saltwater and freshwater. PeerJ 9: e10962. DOI: 10.7717/peerj.10962.

Theerawitaya C, Samphumphaung T, Cha-um S, Yamada N, Takabe T. 2014. Responses of Nipa palm (Nypa fruticans) seedlings, a mangrove species, to salt stress in pot culture. Flora-Morphol Distrib Funct Ecol Plants 209 (10): 597-603. DOI: 10.1016/j.flora.2014.08.004

Tomlinson PB. 1994. The Botany of Mangroves. Cambridge University Press, Cambridge, UK. 
Tomlinson PB. 2016. The Botany of Mangroves. 2nd ed. Cambridge University Press, Cambridge, UK.

Utami ASS, Luthfi OM. 2019. Role of local disaster management authority for facing high tide disaster at Pacitan Bay, East Java. J Innov Appl Technol 5 (1): 819-823. [Indonesian]

Utami S, Anggoro S, Soeprobowati TR. 2017. The diversity and regeneration of mangrove on Panjang Island Jepara Central Java. Int J Conserv Sci 8 (2): 289-298. DOI: 10.21776/ub.jiat.2019.005.01.2.

Vitasari M. 2015. Kerentanan ekosistem mangrove terhadap ancaman gelombang ekstrim/abrasi di kawasan konservasi Pulau Dua Banten.
Bioedukasi 8 (2): 33-36. DOI: 10.20961/bioedukasi-uns.v8i2.3870. [Indonesian]

Wicaksono FB, Muhdin. 2015. Komposisi jenis pohon dan struktur tegakan hutan mangrove di Desa Pasarbanggi, Kabupaten Rembang, Jawa Tengah. Bonorowo Wetl 5 (2): 55-62. DOI: 10.13057/bonorowo/w050201. [Indonesian]

Wijayanti T. 2017. Profil pencemaran logam berat pada perairan daerah aliran sungai (DAS) Grindulu Pacitan. Jurnal Ilmiah Sains 17 (1): 1925. DOI: 10.35799/jis.17.1.2017.15057. [Indonesian] 